\title{
Difussion of Inovation of Creative Industry Values on the Tenants of Sragen Tehcno Park Trough Business Incubator Model
}

\author{
Wawan Lulus Setiawan \\ Nurhayat Indra \\ Lely Savitri Dewi
}

Lecturers of Cooperative Institute of Indonesia (IKOPIN)

\begin{abstract}
Currently creative industry in Indonesia is being develops as primary sector in economic development due to its capability to increase the value added of local resources, providing employment, and promoting tourism on the basis of sustainable development principles. Several techno park currently have been being developed by the government in various locations and various sector of economy as the focus of development. Sragen Tecno Park located in Central Java is one of Techno Park which focus on creative industry development trough business incubator model. In 2016 the program was followed by 10 (ten) new entrepreneurs as Tenants. By applying business incubator approach the Tenants were treated through the process beginning from selection, entrepreneurship training, managerial training, technical training, design and creativity training, as well as assistance, consulting, and advocating for marketing activities. Using the participatory action research, this qualitative study finds that business incubator model could improve creative industry values covering entrepreneurship values and art values of the Tenants, beside, supply chain and value chain of creative industry could be developed by the Tenant as well. This resulted in the improvement of business performance of the Tenant. Diffusion of innovation of creative industry values on the tenants trough business incubator model has indicated its effectiveness as an approach to develop Small and Medium Enterprises (SMEs), so that it has implication for policies of developing SMEs in other local resource based economic sector.
\end{abstract}

Keywords: Diffusion of innovation, business-incubator, creative-industry.

\section{Introduction}

Small and medium enterprises (SMEs) in Indonesia are the backbone of the economy. Currently there are 57.7 million SMEs or $99.99 \%$ of total economic actors, providing employment of 107 million to 115 million people or $97.30 \%$, and contributing to the GDP of $58.98 \%$ of total GDP. Business sectors undertaken by SMEs include: (1) agriculture $35.1 \%$, (2) Trade, hotel and restaurant $15.90 \%$, (3) Services $14.71 \%$, (4) Creative industry $11 \%$, (5) ) Manufacture industry $9.22 \%$, (6) transportation and communication $4.44 \%$, (7) finance and real estate $2.3 \%$, and (8) electricity, gases and water $0.2 \%$ (Central Bureau of Statistics, 2013). From this data, the creative industry ranked 4th in its business sector. However, the government in the future is increasingly giving greater attention because of its capability to increase the value added of local resources, providing employment, and promoting tourism on the basis of sustainable development principles. It is proven that the development of creative industries is handled by its own ministries, the Ministry of Tourism and the creative economy.

Creative industry development efforts undertaken by the Government, one of which is done through the establishment of Science Techno Park (STP) Ganesha Sukawati Sragen. This STP is one of 22 Techno Parks that has been built in Indonesia with the main objective to enhance the competitiveness of new business players based on local potential, especially creative industries. STP Ganesha Sukawati, as well as other STPs, is funded by the central government and developed by the Ministry of Research, Technology and Higher Education.

The problems faced by creative industries are the increasingly open and tighter competition resulting from the ASEAN, Asia, and global free markets. This requires the entrepreneurs to continue developing creativity and innovation. The strategy 
undertaken is to increase the capacity of business actors in the field of creative industry, in order to be able to produce products that are highly competitive through a systematic and well programed and development methods. The program is a business incubator. In this case the business incubator can serve as an intermediary institution for the diffusion process of innovation of creative industry values to SMEs community through business incubator tenants.

Based on the above background we conducted a study entitled Diffusion of innovation of creative industry values on the tenants of Sragen Techno Park trough business incubator model. This study is conducted to answer the following questions: (1) Are the values of creative industries that include entrepreneurship, creativity and art value can be diffused to new entrepreneurs in the creative industries business, (2) whether business incubator can be an effective model or approach for diffusing creative industry values, which are indicated by business performance change, (3) How is the policy implication to develop SMEs in Indonesia. This study has been conducted by participative obstructive method to 10 tenant's creative industries in Sragen Techno Park from September 2016 until December 2016.

\section{State of The Art}

This state of the art includes the conceptual framework of the study, the methods undertaken, and the expected output and uniqueness of the study.

a. Conceptual Framework

\section{(1) Creative industries}

Creative industry is a new analytic definition of the industrial components of the economy in which creativity is an input and content or intellectual property is the output (DCMS,1998). Further, The UK Government's Department for Culture, Media and Sport (DCMS) define creative industry as: 'Those industries which have their origin in individual creativity, skill and talent and which have a potential for wealth and job creation through the generation and exploitation of intellectual property. As of 2015 the DCMS definition recognizes nine creative sectors, namely: (1)Advertising and marketing, (2)Architecture, (3)Crafts, (4) Design: product, graphic and fashion design, (5) film, TV, video, radio and photography, (6) IT, software and computer services, (7) Publishing, (8) Museums, galleries and libraries, and (9) Music, performing and visual art.

\section{(2) Diffusion of innovation}

Diffusion is the process by which on innovation is communicated through certain channels over time among the members of a social system. It is a special type of communication, in that the massages are concern with new ideas (Rogers, 1983). Meanwhile, Rogers also define an innovation is an idea, practices, or object that is perceived as new by an individual or other unit of adoption. It matters little, so far as human behavior is concern, whether or not an idea is "objectively" new as measures by the lapse of time since its first use or discovery. The perceive newness of the idea for the individual determines his or her reaction to it. If the idea seem new to the individual, it is an innovation. Rogers then states four main elements in the diffusion of innovation as he defined. The four main elements are the innovation, communication channels, time, and the social system.

In this study, the innovation is industries creative values covering entrepreneurship values, art values, and technological values. These values are intended to diffuse to the Small and Medium enterprises (SMEs) communities through the tenant of business incubator as the channel.

\section{(3) Business Incubator}

Business incubator began in the 1960s and really took off in the late 1990s as support for start-up companies who need advice and venture capital to get their ideas off the ground. Business incubators are programs designed to accelerate the successful development of entrepreneurial companies through an array of business support resources and services, developed and managed by incubator management and offered both in the incubator and through its network of contacts (Tidd, J, et al, 2007). Setiawan (2003) mentioned that business incubator is an education process so that in a business incubator have to be found key elements as follows: (1) input, i.e. the tenant which have been well selected, (2) qualified incubator management and the group of tutors as the educator, (3) curriculum of business incubator, i.e. innovation which will be diffused to the tenant, (4) infrastructure, i.e. facilities which are necessary to support incubation process, (5) methods which are used, consisting of training, tutorial, advocating, consulting, and assistance, (6) output, i.e. the tenants those have passed the program, and (7) environmental and government policy supports (figure 1) 
Figure 1. The system of Business Incubator (Wawan Lulus Setiawan,2003)

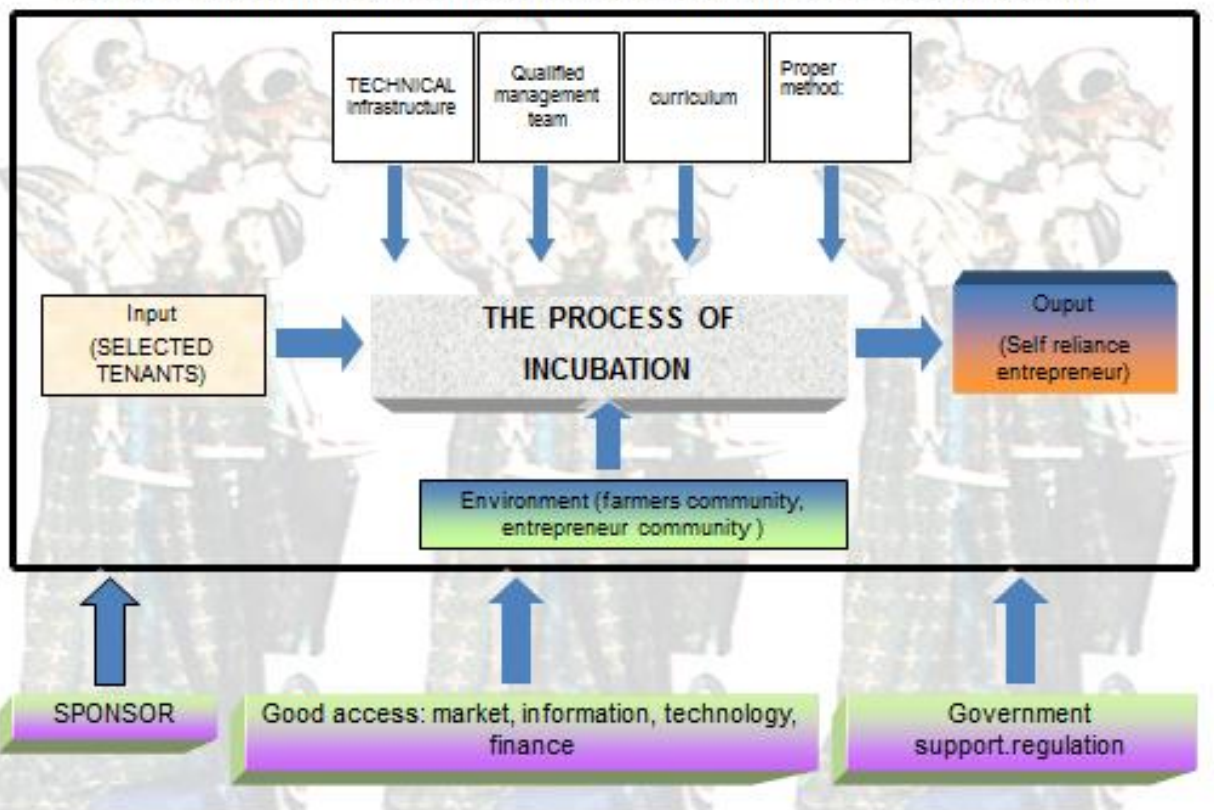

\section{b. Method of Study}

This study used the participatory action research method as one of the qualitative approach. Participatory action research (PAR) is an approach to research in communities that emphasizes participation and action. It seeks to understand the world by trying to change it, collaboratively and following reflection. PAR emphasizes collective inquiry and experimentation grounded in experience and social history. This method works beyond the participant observation method. In this method beside doing research, the researchers think and act a necessary intervention to the subject of the research, so that the researcher could involve in the process and evaluate the behavioral change of the tenants as the subject of research. The subjects of this study are ten tenant of Sragen Techno park in Central Java, Indonesia. This study was carried out from October 2016 until December 2016. The list tenants as the subject of research are as follows:

Table 1. Tenant of Business Incubator Techno park Sragen

\begin{tabular}{|l|l|l|}
\hline No & Name & Business Sector \\
\hline 1 & Mino & Furniture \\
\hline 2 & Danar Nugroho HN & IT, Software \\
\hline 3 & Silvester Adi Suryo & IT, Software \\
\hline 4 & Rahmadi & Jeans \\
\hline 5 & Tunjung Palupi & Handy craft \\
\hline 6 & Sri Sundari & Handy craft \\
\hline 7 & Ana Amelia & Batik, fashion \\
\hline 8 & Suwanto A.R & Batik, fashion \\
\hline 9 & Rina Pandansari & Batik, fashion \\
\hline 10 & Rio Rizky Septianto & IT, software \\
\hline
\end{tabular}

The process of business incubation in which this study was carried out following several steps as follows: 

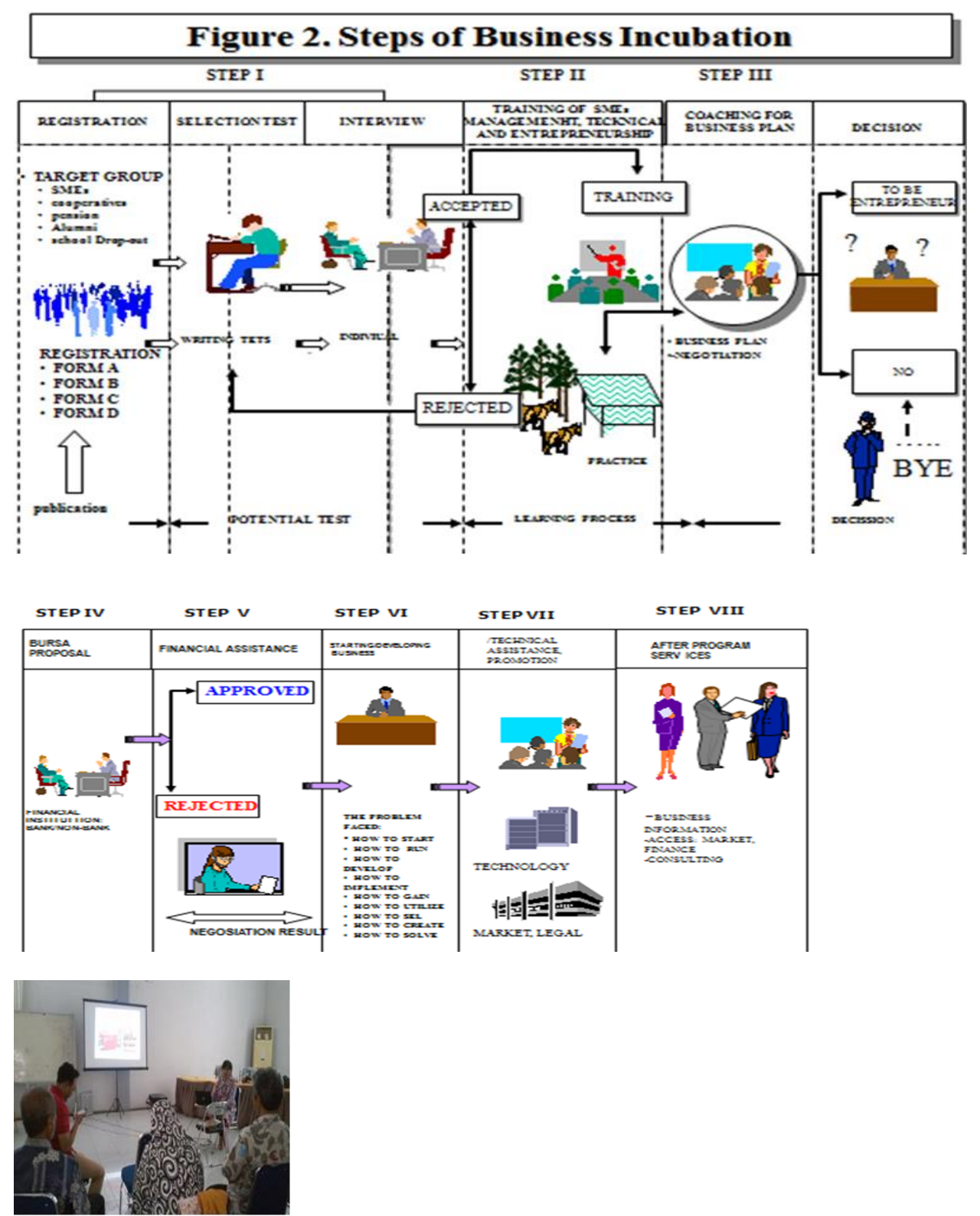

Figure 3.

Training ativities for the tenants of STP Sragen in the subjects of entrepreneurship, business management, art design, legal business aspect, information technology 


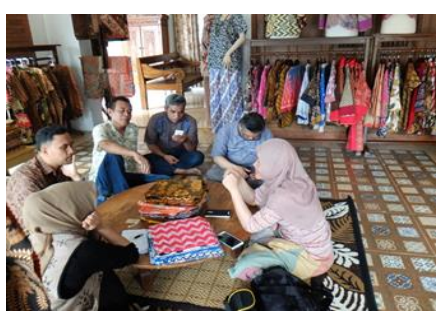

Figure 4.

Site visit to the tenant outlet and production house, discussing some problem and issues faced by tenant business

\section{c. Expected Output}

This study was aimed at answering three research questions as follows: (1) Can the values of creative industries including entrepreneurship values, art values, and technological values be diffused to the new entrepreneurs, (2) Can business incubator be an effective model or approach for diffusing creative industry values, which are indicated by business performance change, (3) How is the policy implication to develop SMEs in Indonesia.

\section{Fact Finding and Result}

\section{a. Diffusion of creative industry value}

Business incubator activities conducted in this study include training, tutorial, consulting, and advocating on the subject of entrepreneurship, business management, legal business aspect, art design, and information technology. From the results of personal entrepreneurship quality measurement to 10 tenants with 10 indicators obtained data as presented in the following figure:
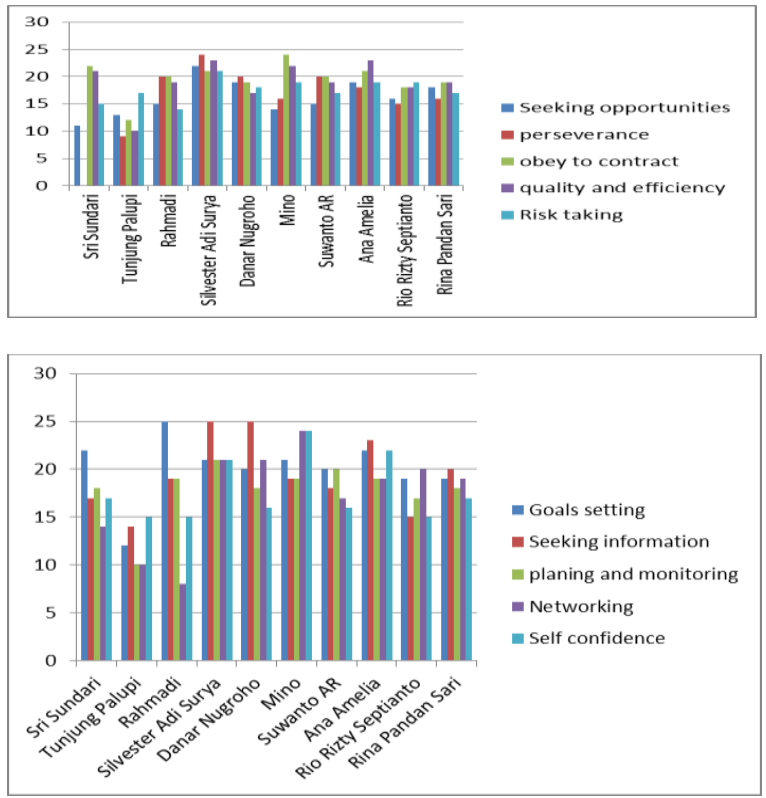

Figure 5. Personal Entrepreneurship Quality of the Tenants of Business Incubator STP Sragen

From the picture It is indicated that the tenant's entrepreneurial potential varies. The tenants then realized their strengths and weaknesses. With this figure, through the process of innovation, entrepreneurial value diffusion has awakened awareness (affective change) on themselves to develop themselves on aspects of entrepreneurial spirit. 
From the aspect of knowledge (cognitive domain) obtained the data of the improvement of knowledge on the subject matter diffused to the tenants as shown in the following table:

Table 2. Score of Cognitive Change of Business Incubator STP Sragen Tenant

\begin{tabular}{|l|l|l|l|l|}
\hline No & Subject Mater & $\begin{array}{l}\text { Average Score } \\
\text { f Pre-test }\end{array}$ & $\begin{array}{l}\text { Average score of } \\
\text { Post-test }\end{array}$ & $\begin{array}{l}\text { Improvement } \\
(\%)\end{array}$ \\
\hline 1 & Entrepreneurship & 55,6 & 72,4 & 30,22 \\
\hline 2 & Business Management & 41,4 & 66,3 & 60,14 \\
\hline 3 & Art Design & 63,5 & 77,4 & 21,89 \\
\hline 4 & Legal Business Aspect & 45,8 & 70,2 & 53,28 \\
\hline 5 & IT & 48,6 & 62,8 & 29,10 \\
\hline
\end{tabular}

The data above shows that the process of diffusion of innovation of creative industry values, entrepreneurship, art design, and IT conducted to 10 tenants through incubation process in generally has an effect on cognitive tenant change which is good enough.

\section{b. Effectiveness of business incubator}

The effectiveness of the business incubator as a diffusion of innovation media for the values of the creative industries is evaluated by assessing the change of tenants' business performance between before incubation program and after incubation program. A description of the change in business performance is presented in Table 3.

Table 3. Business performance Change of Business Incubator STP Sragen Tenants

\begin{tabular}{|l|l|}
\hline Before Incubation & After Incubation \\
\hline Managerial and IT aspect & Business profile available \\
\hline Business profile not available & Business plan available \\
\hline Business plan not available & Book keeping available \\
\hline Book keeping not available & Marketing information system available \\
\hline Marketing information system not available & In progress \\
\hline Business Legal aspect & In progress \\
\hline Legal standing not available & In progress \\
\hline Legal business permit not available & \\
\hline Intellectuals property right not available &
\end{tabular}



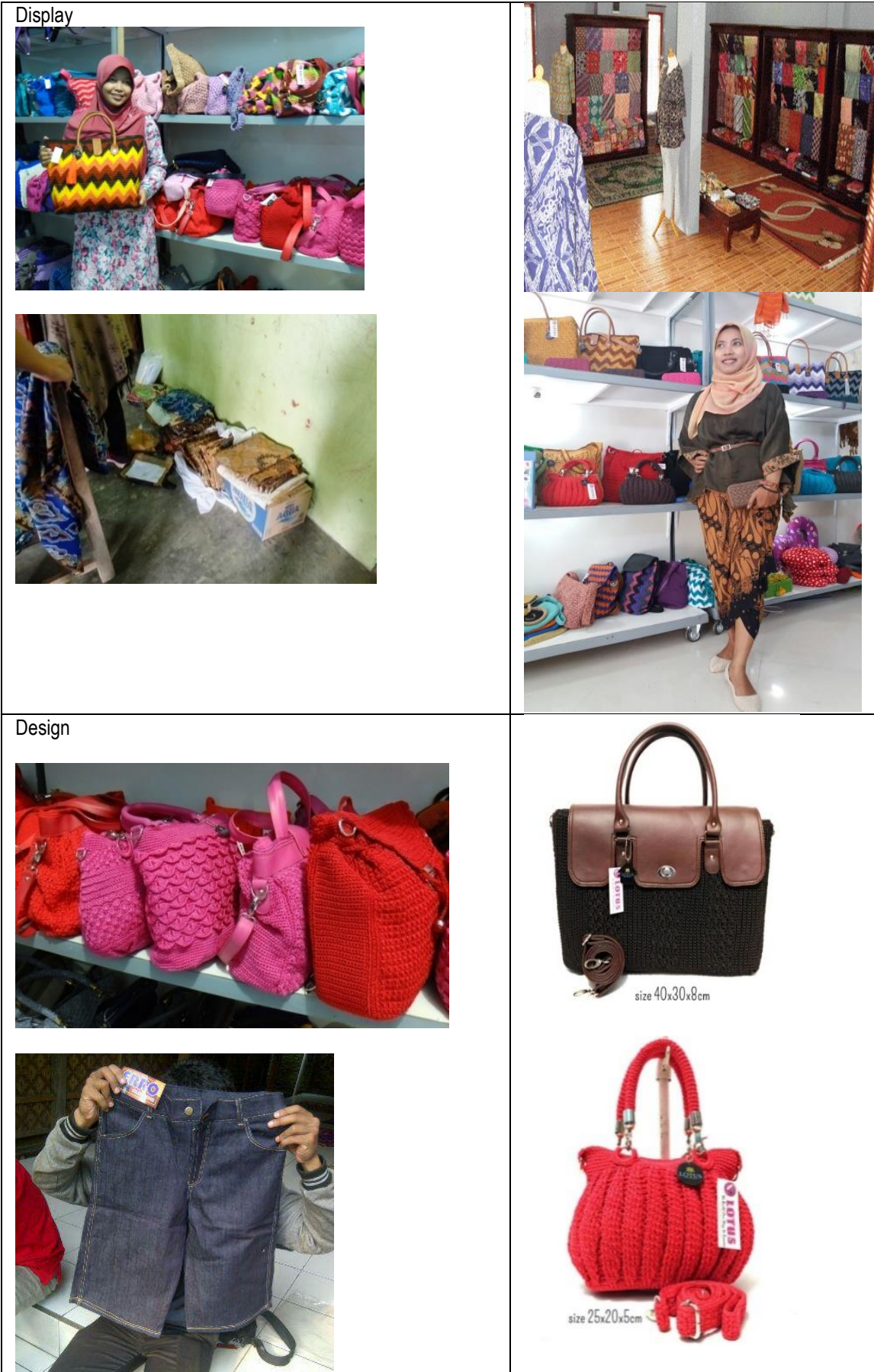


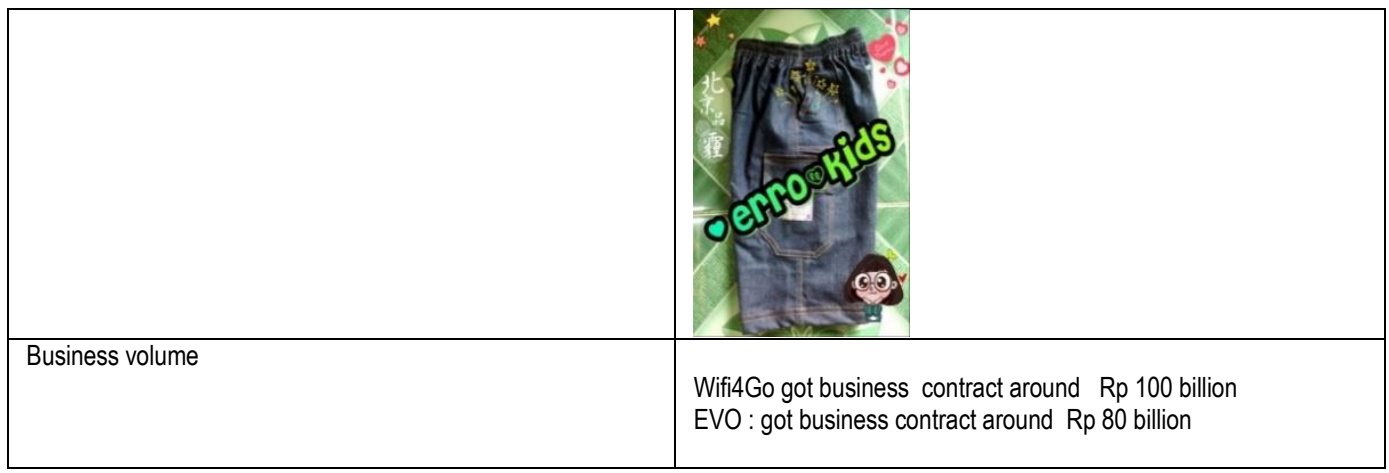

The table 3 indicates that in general there has been a change in the business performance of tenants, except for the aspect of business volume, just two tenants that has shown the increase, especially the tenants of the creative IT business. While other tenants have not indicated an increase in business volume. This is because the duration of the incubation program is too short (only 3 months). In addition, the provision of space facilities and equipment for tenants late, just provided before the program ends.

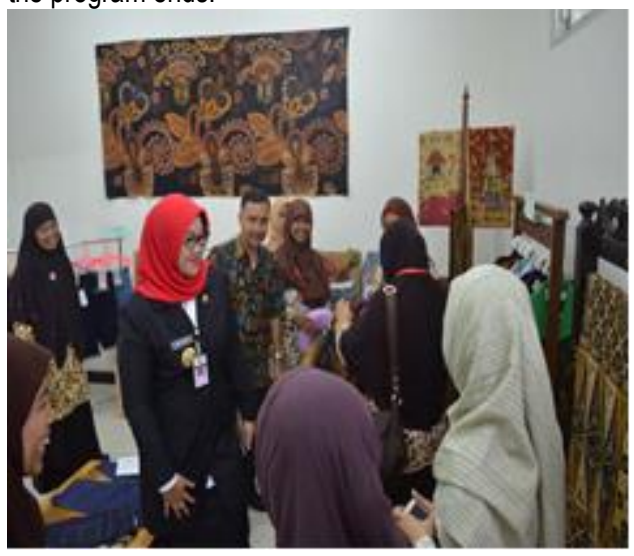

Figure 6.

Inauguration of Business Incubator of STP Sragen by Sragen Regent during the promotion of tenant product to Sragen regency community.

\section{c. Policy Implication}

Based on the fact finding of this study, it can be underscored that Sragen STP's business incubation program effectively diffuses the values of the creative industries to the tenants. In addition, the fact finding of this study shows the strengths and weaknesses of the Sragen STP business incubator program. Its strengths are; (1) Process sequences is systematic, (2) Selection process of the tenants was tightly done, (3) the number of tenants had been adjusted to the business incubator capacity, (4) the subject matter was formulated from the results of accurate need assessment, (5) the support of the central government And local government consistent, and (6) sufficient quantity and quality of instructor staff. The weakness are (1) the duration of the program was too short, i.e. 3 months. Whereas the incubation program is done at least in one full year, (2) the time of providing facilities and space for tenants was rather late, (3) the incubation process was mostly done out-wall.

Based on the fact finding, the policy implication is to continue and disseminate similar business incubator models at 22 Techno Park in Indonesia, with a broader business sector, with improvements to the program by paying attention to those weaknesses. 


\section{Conclusion}

From the results of this study can be summarized as follows:

(1) Business incubation programs can diffuse the values of the creative industry

(2) The business incubation program has been effective as an approach to the diffusion of creative industry values innovation which is shown by being able to change the business performance of tenants.

(3) The policy implication of this study is that the business incubator program is recommended to be nationally disseminated

\section{References}

[1] Central Bureau of Statistics of Indonesia (BPS). 2013

[2] DCMS. 1998. Creative Industries Mapping Document. DCMS. London

[3] DCMS. 2015. Creative industries economic estimates. Ed Vaizey MP, and The Rt Hon John Whittingdale MP. London

[4] Http://en. Wikipedia:org/wiki/business_incubator

[5] https://en.wikipedia.org/wiki/participatory_action_research_hackersafe

[6] https://en.wikipedia.org/wiki/Participatory action research

[7] Rogers, Everett M. 1983. Diffusion of Innovations. Third Edition. The Free Press. New York. p.6

[8] Tidd, J, et.al. 2007. In Lubica Lesakova. The Role of Business Incubator in Supporting The SMEs Start-Up. Journal Acta Polytechnica Hungarica. Vol.9,No3, 2012. P.85

[9] Setiawan, Wawan Lulus. 2003. Business Incubator in entrepreneurial economic development strategy. Pusat Inkubator Bisnis ITB. Bandung 